\title{
Między stłumieniem a autentycznością. Metafora Don Carlosa w filmie Leontine Sagan Dziewczęta w mundurkach
}

\begin{abstract}
Mazur Daria, Między stłumieniem a autentycznością. Metafora Don Carlosa w filmie Leontine Sagan Dziewczęta w mundurkach [Between Suppression and Authenticity. The Metaphor of Don Carlos in Leontine Sagan's Movie Mädchen in Uniform]. „Przestrzenie Teorii” 32. Poznań 2019, Adam Mickiewicz University Press, pp. 143-166. ISSN 1644-6763. DOI 10.14746/pt.2019.32.7.

The article is a comprehensive analysis of the intertextual references to Frederick Schiller's tragedy Don Carlos in Leontine Sagan's movie Girls in Uniform (Mädchen in Uniform, 1931). The author considers the complex circumstances of the cooperation between the director and the artistic director, Carl Froelich, during the production. Moreover, she also presents the literary basis for the movie, namely the tragedy by Christy Winsloe (Gestern und Heute - Yesterday and Today). On this basis, the author analyses the multilevel presence of two phenomena in the movie: suppression and authenticity, which are related to the metaphor of Don Carlos and the plot of love between two women. The contexts for the analysis are inspired by research in the anthropology of romanticism, psychoanalysis, the psychology of sexual identity, and research on the works of Frederick Schiller.
\end{abstract}

KEYWORDS: Weimar Republic Cinema, intertextuality, homotextuality, suppression, authenticity, woman director

Nakręcone w 1931 roku Dziewczęta w mundurkach (Mädchen in Uniform) są balansującym między stłumieniem a autentycznością obrazem filmowym, ukształtowanym pod wpływem konfrontacji oraz negocjacji dwóch ambiwalentnych sił i związanych z nimi odmiennych ideowych koncepcji, estetyk, wartości, realizatorskich technik ${ }^{1}$. Adaptacja popularnej sztuki Wczoraj i dziś (Gestern und Heute) ${ }^{2}$, powstałej pod wpływem osobistych

${ }^{1}$ Hertha Thiele w wywiadzie udzielonym Karoli Gramann i Heide Schlüpmann podkreśla ową rozbieżność punktów widzenia realizatorów - reżyserki filmu Leontine Sagan i kierownika artystycznego Carla Froelicha. Zob. Hertha Thiele interviewed by Karola Gramann and Heide Schlüpmann, <http://tlweb.latrobe.edu.au/humanities/screeningthepast/reruns/thiele. html> [dostęp: 10.09.2019]. Film wyprodukowała niezależna berlińska spółdzielnia Deutsche Film Gemeinschaft, powołana specjalnie do jego realizacji, a kręcono go w Poczdamie oraz berlińskim studiu Carla Froelicha. Zob. S. Kracauer, Od Caligariego do Hitlera. Z psychologii filmu niemieckiego, tłum. E. Skrzywanowa i W. Wertenstein, Gdańsk 2009, s. 207-208.

${ }^{2}$ Pierwotny jej tytuł brzmiał Der Ritter Nérestan i pod takim tytułem grał ją w 1930 roku teatr w Lipsku, miała ona następnie, już jako Gestern und Heute, wystawienia w Berlinie 
młodzieńczych doświadczeń, naznaczona została przez zderzenie ze sobą żeńskiej wizji - autorki dramatu, będącej zarazem współautorką scenariusza Christy Winsloe ${ }^{3}$, oraz reżyserki Leontine Sagan ${ }^{4}$ (współpracujących na planie z plejadą aktorek zawodowych i nieprofesjonalnych ${ }^{5}$ - z męskimi wyobrażeniami tej produkcji reprezentowanymi przez Carla Froelicha, jako kierownika artystycznego pełniącego rolę współreżysera ${ }^{6}$. Różne za-

reżyserowane przez Leontine Sagan, które zdobyły popularność w środowiskach homoseksualnych. Zob. Hertha Thiele interviewed...; K. Fest, Yesterday and/or Today. Time, History and Desire in Christa Winsloe's Mädchen in Uniform, „German Life and Letters” 2012, nr 65, s. 458; Ch. Winsloe, Gestern und Heute (Ritter Nérestan), Berlin 1930. Dodać należy, że współscenarzystą filmu był młody, debiutujaccy w tej roli pod anagramem F.D. Andam - Friedrich Dammann, który po latach został następnie także współautorem scenariusza filmowej wersji Dziewczat $w$ mundurkach z 1958 roku.

${ }^{3}$ Christa Winsloe była znaną postacią w kręgach towarzyskich oraz popularnych w Berlinie lat dwudziestych klubach dla lesbijek, prowadziła też bardzo aktywne życie zawodowe, jako rzeźbiarka specjalizująca się w wizerunkach zwierząt. Po sukcesie Mädchen in Uniform Winsloe zajęła się pisarstwem, publikując w Anglii i Holandii, gdyż jej książki były w III Rzeszy zakazane. Powieściowa wersja sztuki z 1933 roku zatytułowana Mädchen Manuela powstała w związku z popularnościa filmu. Miała liczne wydania w wielu krajach. Przed II wojna światową Winsloe związana była z Dorothy Thompson, amerykańską dziennikarką która ostrzegała świat zachodni przed nazizmem. W czasie wojny Winsloe przebywała we Francji i współpracowała z Ruchem Oporu. Została zamordowana przez bandytów wraz z partnerka Simone Gentet, szwajcarską tłumaczka, 10 czerwca 1944 roku niedaleko Cluny. Wyjaśnienia Lamberta - szefa szajki, że zabili kolaborantki, działając na zlecenie Francuskiego Ruchu Oporu, okazały się fałszywe. Zostali oni jednak uniewinnieni z braku dowodów w 1948 roku. Zob. C. Schoppmann, Christa Winsloe (1888-1944), tłum. D. Heymann, Berlin 2005, <www. lesbengeschichte.de> [dostęp: 10.09.2019]; W.M. Bryant, Bisexual Characters in Film: From Anaïs to Zee, Haworth Press 1997; Hertha Thiele interviewed...

${ }^{4}$ Leontine Sagan była austriacko-węgierską aktorką i reżyserką teatralną pochodzenia żydowskiego, a jej dotychczasowe doświadczenia zawodowe, artystyczne związane były z austriacką i niemiecką sceną teatralna. Współpracowała m.in. z Maxem Reinhardtem. Zob. Hertha Thiele interviewed...; Leontine Sagan. Licht und Schatten. Schauspielerin und Regisseurin auf vier Kontinenten, red. M. Eckardt, Berlin 2010; L. Kruger, Lights and Shadows: The Autobiography of Leontine Sagan, Johannesburg 1996; G. Foster, Women Filmmakers and Their Films, Detroit 1998, s. 361-362; A. Acker, Reel Women. Pioneers of the Cinema, 1896 to the Present, New York 1991, s. 320-322; G.A. Foster, Women Film Directors: An International Bio-Critical Dictionary, Greenwood Press 1995, s. 322.

${ }^{5}$ W głównych rolach wystapiły: Hertha Thiele jako Manuela oraz Dorothea Wieck jako wychowawczyni, panna von Bernburg.

${ }^{6}$ Zob. T. Kłys, Od Mabussego do Goebbelsa. Weimarskie filmy Fritza Langa i kino niemieckie do roku 1945, Łódź 2013, s. 83; S. Kracauer, dz. cyt., s. 208. Valerie Weinstein w swym artykule wskazuje na czynniki propagandowe, które wpłynęły na wymazywanie w III Rzeszy roli reżyserki Leontine Sagan - Żydówki, a zarazem eksponowanie jako realizatora filmu Carla Froelicha, jak również na celowe niedostrzeganie wątku lesbijskiego. Zob. tejże, The Uniform in the Closet: Mädchen in Uniform in Nazi Germany, „Seminar. A Journal of Germanic Studies" 2019, nr 2, s. 144-158. Carl Froelich był specjalistą kina gatunkowego, reżyserem popularnych filmów z Hansem Albersem, Zarą Leander i Ingrid Bergman. W 1933 roku 
łożenia realizatorskie i warunkowany nimi wybór środków artystycznych, w tym kluczowego odwołania intertekstualnego, wpłynęły na przejawianie się w filmowej opowieści dwóch ambiwalentnych czynników - stłumienia oraz autentyczności. Oscylowanie między nimi miało swój związek również z problematyką podjętą w pierwowzorze literackim - młodzieńczą miłością, która Manuela - dojrzewająca uczennica poczdamskiej szkoły z internatem dla ubogich córek pruskich oficerów - obdarza charyzmatyczną wychowawczynię; świadomość zaś tego zakazanego w opresyjnym systemie uczucia popycha główną bohaterkę dramatu do samobójstwa, nim ktokolwiek zorientuje się, jaka jest jego przyczyna ${ }^{7}$.

Na planie Dziewczat $w$ mundurkach nastapiła więc konfrontacja emocjonalności, ekspresyjności, zawartego w dramacie Winsloe osobistego świadectwa z pragmatyzmem i rzemieślniczym kunsztem doświadczonego filmowca, którym był Froelich ${ }^{8}$. Wiązała się ona z procesem projekcji własnych emocji Winsloe na stworzona przez Herthe Thiele kreację Manueli, która stała się głównym ośrodkiem delikatnie zaznaczającego się w filmie wątku lesbijskiego. Autorka dramatu wywarła też wpływ na obsadę głównej bohaterki i ostateczny wybór aktorki, która miała w swej dotychczasowej teatralnej karierze podobne role ${ }^{9}$. Należy jednakże podkreślić, że typ urody Herthy Thiele, swoista dziewczęcość rysów jej twarzy i drobna budowa ciała pozwalały zarazem Froelichowi na wysubtelnienie wątku kobiecego uczucia i tonowanie napięcia homoerotycznego. Fakt, że aktorka ta grała już wcześniej Manuelę podczas wystawienia sztuki przez teatr w Lipsku, pomagał mu uzyskać pożądany efekt, ponieważ spektakl (w odróżnieniu od berlińskich przedstawień utworu Winsloe) akcentował sieroctwo bohaterki oraz jej pragnienie matczynego uczucia, które prowokowało zbliżenie do sie-

wstapił do NSDAP, a 30 czerwca 1939 roku jako reżyser senior tworzący filmy gloryfikujące niemieckiego ducha, został prezesem Reichsfilmkammer i pełnił tę funkcję do 1945 roku, aktywnie współpracując z aparatem propagandy goebbelsowskiej. Zob. T. Kłys, dz. cyt., s. 142; B. Drewniak, Teatr i film Trzeciej Rzeszy. W systemie hitlerowskiej propagandy, Gdańsk 2011, s. 216, 419; T. Małyszek, Światłopisanie. Film niemiecki 1895-2010, Wrocław 2013, s. 131; A. Gwóźdź, Zaklinanie rzeczywistości: filmy niemieckie i ich historie 1933-1949, Wrocław 2018.

${ }^{7}$ Należy też zwrócić uwagę, że zgodnie z interpretacją Kerstin Fest, która w swym artykule analizuje kontekst historyczno-politycznych odwołań sztuki Christy Winsloe oraz jej wybranych adaptacji scenicznych i filmowych, istotnym wątkiem we Wczoraj $i$ dziś była zapowiedź dziejowych przemian niesionych wraz z upadkiem cesarskich Niemiec i narodzinami Republiki Weimarskiej. Natomiast rzeczywistość filmowa Dziewczat w mundurkach nie jest według Kerstin Fest ściśle dookreślona czasowo. Zob. tejże, dz. cyt., s. 457-471.

${ }^{8}$ Hertha Thiele podkreśla w wywiadzie obecność na planie i zaangażowanie w produkcję autorki dramatu. Zob. Hertha Thiele interviewed...

${ }^{9}$ Grała ona młodą lesbijkę w sztuce Die Kreatur Ferdynanda Brucknera. Leontine Sagan chciała tymczasem, by rolę Manueli odtwarzała Gina Falckenberg - aktorka, z która współpracowała przy berlińskim przedstawieniu. Zob. Hertha Thiele interviewed... 
bie wychowawczyni i uczennicy ${ }^{10}$. Subtelny ekranowy wizerunek wrażliwej i melancholijnie spoglądającej Manueli miał sugerować widzom opiekuńczy aspekt, jako dominujący w relacji łączącej ją z panną von Bernburg.

Leontine Sagan, przystępując do realizacji Dziewczat $w$ mundurkach, jako reżyserka i aktorka teatralna, a więc specjalistka z innego obszaru artystycznego, musiała polegać na wiedzy i profesjonalizmie Froelicha, jednakże jej dystynkcja, umiarkowanie oraz inteligencja sprawiły, że nie wytworzył się jawny konflikt między reżyserską parą ${ }^{11}$. Hertha Thiele wspomina, że stosunek Sagan do pracy aktorek na planie naznaczony był przez intelektualizm, analityczność, nie emocjonalność, a zarazem potrafiła ona też twórczo wyzyskać realizatorskie koncepcje Froelicha, który usiłował uniknać teatralizacji, przerysowania, emocjonalnego kiczu ${ }^{12}$. Zaproponował on modyfikację wątku samobójstwa głównej bohaterki, co Sagan wykorzystała, by nadać filmowi wymowę powiązaną nie tylko z dramatycznymi losami jednostki, ale też z motywem wspólnotowej solidarności uczennic. Froelich jako doświadczony reżyser wiedział, w jaki sposób zapobiegać wyrazistej ekspresji wątków homoseksualnych, których eksponowanie nie leżało w jego założeniach recepcyjnych ${ }^{13}$. Świadomy był również tego, jak można wydobyć na ekranie walory dziewczęcej, kobiecej urody i dzięki nim odnieść komercyjny sukces. Froelich, dobrze znając język kina, zdawał sobie sprawę, w jaki sposób oddziaływać na wyobraźnię męskiej części widowni, kreując aurę wokół wybranych postaci kobiecych, bez banalnych estetycznych rozwiąań, ale też i bez jednoznacznych, odważnych obyczajowo sugestii ${ }^{14}$. Żeńska wizja artystyczna Dziewczat $w$ mundurkach musiała więc być negocjowana, nie bez związku z owym założonym męskim odbiorca. Jednak trzeba też zaznaczyć, że film, mimo iż unikał jakiejkolwiek aluzji wprost do homoseksualnej subkultury epoki Republiki Weimarskiej, do modnych ówcześnie zjawisk androginii czy męskich zachowań i stylu podejmowanych przez kobiety, wywołał bardzo duże zainteresowanie w berlińskich środowiskach lesbijskich i przyniósł ogromną popularność aktorkom odtwarzającym główne role ${ }^{15}$.

${ }^{10}$ Zob. tamże.

${ }^{11}$ Zob. tamże. Tomasz Kłys podkreśla, że kolejne dwa filmy Sagan realizowała w Wielkiej Brytanii również we współpracy z uznanymi reżyserami: w 1932 roku z Zoltanem Korda Men of Tommorow - nieudaną próbę męskiej wersji Dziewczat w mundurkach, a w 1946 roku musical Gaiety George z George'em Kingiem, inspirowany wspomnieniami George'a Edwardesa. Późniejszy etap jej kariery związany był już wyłącznie z teatrem w Pretorii, dokąd jako Żydówka wyemigrowała wraz z mężem. Była ona założycielką Teatru Narodowego w Johannesburgu. Zob. T. Kłys, dz. cyt., s. 83-84.

${ }^{12}$ Zob. Hertha Thiele interviewed...

${ }^{13}$ Zob. tamże.

${ }^{14}$ Zob. tamże.

${ }^{15}$ Zob. tamże; K. Fest, dz. cyt., s. 466; A. Kuzniar, Hesitancy and Hovering: Irony, Camp, and Fetishism in Mädchen in Uniform, „Seminar. A Journal of Germanic Studies” 2019, nr 2, s. 102. 
Należy więc podkreślić, że w wyniku opisanej konfrontacji postaw realizatorskich, następowało nieoczywiste przenikanie się elementów, przeplot wyobrażeń ufundowanych na różnych preferencjach. Punkt widzenia kobiet autorek ${ }^{16}$, okazał się otwarty na konteksty wykraczające poza wątek miłosny, co pozwoliło na wyeksponowanie w fabule tematu opresji w żeńskiej szkole, a przede wszystkim rodzącego się wobec niej buntu, który krytycy interpretowali jako niezgodę na mechanizmy rządzące systemem pruskiej edukacji ${ }^{17}$. Odwołujący się do tego motywu sposób odczytania Dziewcząt $w$ mundurkach jako filmu o wymowie prodemokratycznej, przeciwnej autorytaryzmowi, militaryzmowi na długi czas zdominował krytyczne analizy tego filmu. B. Ruby Rich podjęła próbę rozważenia jego wymowy, uwzględniając dwie alternatywne wersje: protoantyfaszystowska, zgodnie z która humanitarny idealizm przeciwstawiony zostaje autorytarnej władzy i ustanowionemu przez nią nieludzkiemu porządkowi, oraz antypatriarchalna, stanowiąca wyraz emocjonalnej wolności kobiet i przede wszystkim ufundowaną na motywie miłości lesbijskiej ${ }^{18}$. Uzasadniona

${ }^{16}$ Związany był on z jawnie deklarowaną lesbijską orientacją Christy Winsloe. Natomiast, pomimo że nie ma pewnych przesłanek w odniesieniu do Leontine Sagan, to Gwendolyn A. Foster określa ją tak w swym słowniku. Zob. tejże, Women Film Directors...

${ }^{17}$ Zob. Hertha Thiele interviewed... Kwestię odmiennych wersji treści utworu Christy Winslow, w powiązaniu z jego różnymi adaptacjami, szeroko analizuje w swym artykule Kerstin Fest. Zob. tejże, dz. cyt. Należy jednak też zaznaczyć, że niektórzy krytycy, np. Siegfried Kracauer oceniali film jako nie dość wyrazisty w podjęciu problemu władzy autorytarnej. Zob. tegoż, dz. cyt., s. 207-210.

${ }^{18}$ Zob. B.R. Rich, Chick Flicks: Theories and Memories of the Feminist Film Movement, Duke University Press 1998, s. 180-181. Por. V. Russo, The Celluloid Closet. Homosexuality in the Movies, New York 1995, s. 43-45; R. Dyer, Now You See It. Studies on Lesbian and Gay Film, New York-London 1990; S.G. Jones, Mädchen in Uniform: the Story of a Film, "PerVersions: The International Journal Of Gay And Lesbian Studies" 1995/1996, nr 6; S. Brockmann, A Critical History of German Film, New York 2010, s. 49; T. Kłys, dz. cyt., s. 82-83; V. Mayer, Lesbian Classics In Germany? A Film Historical Analysis of Mädchen in Uniform (1931 and 1958), „Journal of Lesbian Studies” 2012, nr 3, s. 340-353; J. Barker, Indifference, Identification, and Desire in Virginia Woolf's Three Guineas, Leni Riefenstahl's The Blue Light and Triumph of the Will, and Leontine Sagan's Mädchen in Uniform, "Women in German Yearbook" 2010, nr 1, s. 73-96; E. Krimmer, Ideology's Work Is Never Done: A New Historicist Reading of Mädchen in Uniform, "West Virginia University Philological Papers" 1999, nr 45, s. 38-46; R. McCormick, Coming Out of the Uniform: Political and Sexual Emancipation in Leontine Sagan's Mädchen in Uniform (1931), [w:] Weimar Cinema: An Essential Guide to Classic Films of the Era, red. N.W. Isenberg, Columbia 2009, s. 271-289; L. Ohm, The Filmic Adaption of the Novel The Child Manuela: Christa Winsloe's Child Heroine Becomes a Girl in Uniform, Gender and German Cinema: Feminist Interventions, red. S. Frieden i in., Berg 1993, s. 97-104; N. Zimnik, No Man, No Cry? The Film Girls in Uniform and Its Discourses of Political Regime, "Women in German Yearbook" 1999, nr 15, s. 161-183. Należy zaznaczyć, że Alice Kuzniar koncentruje uwagę w odniesieniu do kwestii tożsamości lesbijskiej na powiązanym z nią wahaniu, zawieszeniu, niepewności. Zob. tejże, dz. cyt., s. 94-109. 
jest interpretacja, w której oba wspomniane przewodnie wątki nakładaja się i uzupełniają. Należy zaznaczyć jednak, że Ruby Rich nie uwzględniła ważnego kontekstu, a więc udziału w produkcji Carla Froelicha i jego wpływu na kształtowanie tego filmowego obrazu przez Leontine Sagan i Christe Winsloe ${ }^{19}$.

Wnikliwe rozpatrzenie uwarunkowań realizacji, a przede wszystkim struktury Dziewczat $w$ mundurkach w celu określenia genezy i funkcji zawartej w niej literackiej metafory, wiąże się zarazem z odsłonięciem związków owego odwołania z kategoriami stłumienia i autentyczności, które moderowały fluktuacje dwu koncepcji realizatorskich. Warto przypomnieć, że idea autentyczności to „przewodni motyw nowoczesnego poszukiwania fundamentu jednostkowej tożsamości” ${ }^{20}$. Badacze wskazują na jej źródła w oświeceniowym odrzuceniu religijnych ram dla jednostki i nowożytnym formowaniu się osobowości ${ }^{21}$. Bardzo znaczący wpływ na kulturę autentyczności miały jej romantyczne wzorce, powiązane z ideałem ,jednostkowej niepowtarzalności”22, głoszonym przez Fryderyka Schillera oraz z rozwijana przez niego koncepcją estetyzacji, gdyż ona „w naturalny sposób odsyła do sztuki i literatury jako procesów twórczych, które w kulturze autentyczności stają się wzorcem kształtowania osobowości i zarazem zwierciadłem, w którym autentyczności może się odbijać” ${ }^{23}$. Zgodnie z antropologią romantyczna powstaje ona w wyniku konfrontacji wyobraźni i natury, w obszarze „napięcia między rzeczywistością i fikcją"24. Rozważając ideę autentyczności, Michał Warchala przywołuje metaforę teatru Ervinga Goffmana, wyprowadzając z niej koncepcję publicznej tożsamości - roli jako maski, będącej tylko symbolem tego, co wewnętrzne, a więc w konsekwencji dychotomii publicznego i prywatnego ${ }^{25}$. Należy też przypomnieć, że w psychoanalitycznym ujęciu Zygmunta Freuda autentyczność polega na heroicznym zmaganiu się w ramach dynamiki libidalnej - popędu Erosa i popędu śmierci, dla zachowania rzeczywistości psychicznej ${ }^{26}$. Zgodnie zaś z ustaleniami psychologii pozytywnej, w której kategoria autentyczności odgrywa również istotną rolę, mechanizmy obronne, wyróżnione i scharakteryzowane przez Freuda, sąjej

\footnotetext{
${ }^{19}$ Zob. B.R. Rich, dz. cyt., s. 179-206.

${ }^{20} \mathrm{M}$. Warchala, Autentyczność $i$ nowoczesność. Idea autentyczności od Rousseau do Freuda, Kraków 2006, s. 30.

${ }^{21}$ Zob. tamże, s. 21.

${ }^{22}$ Tamże, s. 26.

${ }^{23}$ Tamże, s. 21. Por. tamże, s. 26-28.

${ }^{24}$ Tamże, s. 32. Por. tamże, s. 31.

25 Zob. tamże, s. 23-25.

${ }^{26}$ Zob. tamże, s. 33. Kwestie te analizuje Agata Bielik-Robson w rozdziale Niepokoje młodego libido: Freud monografii Erros. Mesjański witalizm i filozofia, Kraków 2012.
} 
przeciwieństwem; stawiają one przeszkody na drodze do niej, wypaczając i odmieniając rzeczywistośćc ${ }^{27}$.

Należy więc też zaznaczyć, że wśród mechanizmów obronnych stłumienie (supresja), jako świadomy odpowiednik mechanizmu wyparcia (represji), stanowi technikę unikania działania, która polega na świadomym odwróceniu uwagi od pewnej aktualnie świadomej treści psychicznej, na skutek czego myśl staje się przedświadomą ${ }^{28}$. Zgodnie z założeniami psychoanalizy bezpośrednią motywacją tłumienia są opory moralne, których źródłem jest druga cenzura, między świadomością a przedświadomością. Ego zwraca się przeciwko uczuciom, które towarzyszą zakazanemu procesowi popędowe$\mathrm{mu}^{29}$. Nancy McWilliams zauważa, że „tłumienie niechcianych impulsów, uczuć, wewnętrznych konfliktów oraz wspomnień, ma charakter adaptacyjny, umożliwiając przystosowanie się do otoczenia, realizację celów oraz zadań jednostki” ${ }^{30}$. W rezultacie prowadzi to do przyswojenia mechanizmów obronnych, takich jak tłumienie pragnień i dążeń niezgodnych z wymaganiami i usunięcia ich poza pole świadomości ${ }^{31}$. Obie kategorie: stłumienie i autentyczność swym oddziaływaniem i powiązanymi z tym uwarunkowaniami obejmują więc nie tylko kondycję głównej bohaterki Dziewcząt $w$ mundurkach, ale także wpisują się immanentnie w status rzeczywistości przedstawionej filmu. Egzystencja społeczności żeńskiej szkoły z internatem, zarówno jej młodszych przedstawicielek, jak i starszych, jest dookreślana przez te czynniki ${ }^{32}$. Obie kategorie sa zarazem powiązane również $\mathrm{z}$ intertekstualna obecnościa, treściami oraz przesłaniem przywołanej w filmie literackiej metafory - Don Carlosa ${ }^{33}$.

Unikalna w owym czasie współpraca dwóch silnych kobiecych osobowości Sagan i Winsloe, w obrębie zdominowanej przez mężczyzn dziedziny produkcji filmowej, miała swój ważny aspekt. Obie autorki odróżniał od Carla Froelicha przede wszystkim założony model ideowy dzieła. Usiło-

${ }^{27}$ Zob. S. Joseph, Autentyczność. Jak być sobq $i$ dlaczego jest to ważne, tłum. A. Jacewicz, Poznań 2016, s. 103-104. Por. Psychologia pozytywna w praktyce, red. P.A. Linley, S. Joseph, tłum. A. Jaworska-Surma, Warszawa 2007.

${ }^{28}$ Zob. E. Cichoń, R. Szczepanowski, Mechanizmy ttumienia niepożadanych odczuć i myśli w ujęciu metapoznawczym, „Rocznik Kognitywistyczny” 2015, nr 8, s. 80; M.H. Erdelyi, The Unified Theory of Repression, "Behavioral and Brain Sciences" 2006, nr 29, s. 499-511; A. Freud, Ego i mechanizmy obronne, tłum. M. Ojrzyńska, Warszawa 2012, s. 80.

${ }^{29}$ Zob. A. Freud, dz. cyt., s. 51.

${ }^{30}$ N. McWilliams, cyt. za: E. Cichoń, R. Szczepanowski, dz. cyt., s. 81.

${ }^{31}$ Zob. B.H. Stoodley, The Concepts of Sigmund Freud, Free Press 1959.

${ }^{32}$ Ważne w tym kontekście są ustalenia zawarte w rozdziale Lęk popędowy w okresie dojrzewania pracy Ann Freud Ego i mechanizmy obronne. Zob. tejże, dz. cyt., s. 110-122.

${ }^{33}$ Zob. F. Schiller, Don Carlos, tłum. K. Iłłakowiczówna, Warszawa 1954. 
wały one stworzyć obraz „homotekstualny” ${ }^{34}$, który dotykałby kontekstów płci, seksualności, miłości wpisanych w wątek lesbijski. Konstytutywnym czynnikiem dla zjawiska homotekstualności jest opór, z którym łączą się społeczna cenzura i autocenzura, opresja homofobiczna, ignorancja, „filtr heteroseksualny" narzucony kulturze ${ }^{35}$. Właśnie w oporze ma swe źródło mechanizm tekstualizacji tożsamości i treści homoerotycznych poprzez ich przebranie, zakodowanie w tekst i wizualne maski, co implikuje nadmiar znaczeń, podwójność sensów, a zarazem ich niestabilnośćs ${ }^{36}$. Odkrycie homotekstualnego przekazu nie jest więc zadaniem łatwym, szczególnie może je utrudniać wspomniany już heteroseksualny filtr, który ogranicza i narzuca gotowe, zgodne z nim, modele odczytania. Figura tekstualna wpisana w film Dziewczęta w mundurkach, zgodnie z mechanizmem intertekstualności, opartym na transpozycji jednego znaku na inny i jego ponownej artykulacji, pozwalała więc na zakodowanie przesłania całego filmu ${ }^{37}$.

Zarówno autorka pierwowzoru literackiego, jak również reżyserka filmu były związane ze środowiskiem teatralnym i doskonale znały sceniczne środki ekspresji. Miało to wpływ na dokonany przez nie wybór metafory tekstu dramatycznego Don Carlosa, a więc jego intertekstualna obecność w Dziewczętach $w$ mundurkach na poziomie fabularnym, nie tylko jako swoistej maski, ale zarazem także katalizatora ekspresji ideowych treści filmu. Należy więc zaznaczyć, że dla ich właściwego odsłonięcia i interpretowania koncentracja na poziomie środków ekranowej adaptacji pierwowzoru literackiego, a więc sztuki Christy Winsloe, zatytułowanej Wczoraj i dziś, nie jest decydująca. Ponieważ, jak przekonują Kerstin Fest oraz Ruby Rich, dramat ten w o wiele mniej radykalny sposób podejmował lesbijski wątek, zaś jego teatralne inscenizacje w mniejszym stopniu eksponowały również przejawy patriarchalnej siły ${ }^{38}$. Przede wszystkim literacki pierwowzór, podobnie jak jego późniejsza powieściowa wersja, która powstała w związu z popularnością filmu, ukazywał - jak określa to Ruby Rich - „całkiem grzeczny model lesbijskiej bajki”39. Elaine Marks upatrywała jego źródeł w powiązanym z tradycja saficką obrazie, stanowiącej odtworzenie relacji z nieżyjąca już matką, miłości uczennicy do adorowanej, uwodzicielsko

${ }^{34}$ Termin ten zaproponował po raz pierwszy Rudi C. Bleys w odniesieniu do sztuk wizualnych w książce Images of Ambiente. Homotextuality and Latin American Art 1810 - Today, London-New York 2000. Zob. T. Kitliński, P. Leszkowicz, Homotekstualność: homoseksualność i twórczość, [w:] Lektury inności. Antologia, red. M. Dąbrowski, R. Pruszczyński, Warszawa 2007, s. $145-159$.

${ }_{35}$ T. Kitliński, P. Leszkowicz, dz. cyt., s. 153, 154-155.

${ }^{36}$ Zob. tamże, s. 148.

${ }^{37}$ Zob. tamże, s. 151.

${ }^{38}$ Zob. K. Fest, dz. cyt., s. 460, 470-471; B.R. Rich, dz. cyt., s. 194.

${ }^{39}$ B.R. Rich, dz. cyt. 
pięknej, charyzmatycznej wychowawczyni ${ }^{40}$. Ruby Rich zaznacza, że na tego typu motywie odciska piętno szkolny kalendarz, narzucający okres separacji, który wywołuje potrzebę ekspresji publicznej osobistych uczuć uczennicy, obawiającej się rozłąki z ukochaną osobą ${ }^{41}$. Podkreśla ona także, że w utworze Winsloe miłość, którą wychowawczyni darzy podopieczne, ma silną motywację związaną z jej pragnieniem prowadzenia szkoły zgodnie z własnym modelem, zaś młodociana bohaterka popełnia samobójstwo, nim ktokolwiek zorientuje się, jaki jest powód jej desperacji ${ }^{42}$. Ruby Rich zwraca również uwagę, że w sztuce wprost zaznacza się obecność męskiego czynnika poprzez osobę adoratora, konkurenta - instruktora jazdy konnej ${ }^{43}$.

Szczególnie istotny jednakże jest inny element fabularny, nieprzywoływany w interpretacji Ruby Rich, który zdecydowanie odróżnia pierwowzór literacki od filmowej adaptacji. Dramat wystawiany przez uczennice w sztuce Winsloe to utwór Woltera zatytułowany Zaira ${ }^{44}$. Manuela zostaje w nim obsadzona w roli rycerza Nerestana, a więc brata tytułowej bohaterki, mającej poślubić ukochanego - sułtana Orosmana ${ }^{45}$. Fabuła utworu eksponuje wątek nietolerancji krewnych, jako przyczyny tragicznych losów Zairy, a także nieuzasadnionej zazdrości jej przyszłego męża, która - wywołując dramatyczne w skutkach konsekwencje - przywodzi pewne skojarzenia z Ottellem. Wcielenie sceniczne Nerestana - postaci współdziałającej ze swym ojcem Lusignanem w celu udaremnienia ślubu siostry z muzułmaninem, nie jest więc rola, w której może odbijać się uczucie Manueli do ukochanej wychowawczyni. To miłość Zairy i Orosmana jest nieszczęśliwa

${ }^{40}$ Zob. tamże. Wątek ten nawiązuje też do popularyzowanej przez reformatora niemieckiego szkolnictwa Gustava Wynekena idei „erosa pedagogicznego”, która wiązała się z fascynacją i/lub miłością między nauczycielem oraz uczniem tej samej płci. Wyneken wywodził ją z antycznych, platońskich źródeł. Koncepcja ta wygasła tymczasem w związku ze skandalem i osądzeniem jej autora w 1921 roku w wyniku oskarżeń o nieobyczajny charakter relacji z dwoma uczniami. Należy zwrócić uwagę, że w polskiej myśli pedagogicznej wspomniany termin oznaczał rodzaj miłości opiekuńczej, bezinteresownej, zbliżonej do rodzicielskiej (np. w pismach Heleny Radlińskiej, Marii Grzegorzewskiej, Bogdana Nawroczyńskiego, Janusza Korczaka). Zob. T. Maasen, Man - Boy Friendships on Trial: On the Shift in the Discourse on Boy Love in the Early Twentieth Century, [w:] Male Intergenerational Intimacy: Historical, Socio-Psychological, and Legal Perspectives, red. T. Sandfort, E. Brongersma, A.X. van Naerssen, New York 1991, s. 55-56; P. Fijałkowski, Homoseksualność daleka i bliska. Stowa, mity, symbole, Warszawa 2014, s. 119.

${ }^{41}$ Zob. B.R. Rich, dz. cyt., s. 194.

42 Zob. tamże.

${ }^{43}$ Zob. tamże.

${ }^{44}$ Zob. Voltaire, Zaire, Paris 1991.

${ }^{45}$ Zob. Hertha Thiele interviewed... Przypomina o tym także Roman Włodek w monografii poświęconej Jadwidze Andrzejewskiej, która występowała w roli Manueli w przedwojennych polskich teatralnych wystawieniach sztuki Christy Winsloe. Zob. tegoż, Jadwiga Andrzejewska na scenie i ekranie, Kraków-Warszawa 2018, s. 52. 
i niespełniona, a ich losy przerywa dramatyczna śmierć. Źródłem owego literackiego nawiązania w sztuce Winsloe wydaje się więc przede wszystkim nietolerancja jako przyczyna niesprawiedliwych osądów ludzkich oraz w konsekwencji śmierci bohaterów.

Natomiast dla interpretacji idei i przewodnich treści Dziewczqt $w$ mundurkach, uwzględniającej odniesienia do kategorii autentyczności i stłumienia, kluczowe jest właściwe rozpoznanie roli przywołanego w filmie na zasadzie „wyrażenia cudzysłowowego” zupełnie innego niż w pierwowzorze literackim utworu, a więc fragmentu dramatycznego tekstu Don Carlosa Fryderyka Schillera ${ }^{46}$. Wzajemne przenikanie się pierwszoplanowej treści fabuły filmu Dziewczęta w mundurkach i treści dramatu, poprzez włączenie sceny dramatycznej jako elementu diegezy, przebiega zgodnie z klasyfikacja zaproponowana przez Piotra Dobrowolskiego w wersji zbieżnej, w której: „Sytuacja bohatera filmowego - świadomego tego lub nie - ewoluuje w taki sposób, że zbliża go do położenia charakterystycznego dla postaci dramatycznej” ${ }^{47}$. Zaznaczyć należy, że oprócz fragmentu sceny, główny bohater dramatu, a także sam tytuł dzieła Fryderyka Schillera, dzięki jego rozpoznawalności, wyzwalają ładunek znaczeniowy wzbogacający fabułę filmową. Istotne jest więc to, że dyfuzja sensów i nawiązania, które modyfikują i uzupełniaja pierwszoplanowa akcję, zostały oparte na „znanym, obecnym w wyobraźni zbiorowej tekście dramatycznym"48. Poza zaznaczającą się w Dziewczętach $w$ mundurkach paratekstualnością - w postaci wygłoszonego ze sceny fragmentu utworu wraz z fabularnymi konsekwencjami tego zdarzenia, które odnoszą się wprost do ideowej wymowy filmu, należy jednakże uwzględnić także osadzenie wspomnianego nawiązania w szerszym aspekcie twórczości Fryderyka Schillera, co otwiera horyzont interpretacji związanych już nie tylko z indywidualnym doświadczeniem określonej tożsamościowo głównej bohaterki, ale i wspólnotowym - żeńskim ${ }^{49}$.

${ }^{46}$ M.R. Mayenowa, Wyrażenia cudzystowowe. Przyczynek do badań nad semantyka tekstu poetyckiego, [w:] tejże, Studia i rozprawy, wybór i oprac. A. Axer i T. Dobrzyńska, Warszawa 1993.

${ }^{47} \mathrm{P}$. Dobrowolski, Historie równolegte, zbieżne, przeciwstawne. Teatr dramatyczny $w$ filmie jako alternatywa i dopetnienie fabuty, „Kwartalnik Filmowy” 2014, nr 87-88, s. 34.

48 Tamże, s. 36.

${ }^{49}$ Warto w tym kontekście przypomnieć schillerowskie tezy o teatrze, które mają odbicie również w Odzie do radości, a przywoływane sa przez Olgę Dobijankę we wstępie do tomu Goethe i Schiller o dramacie i teatrze. Wybór pism: „rola teatru objawia się zatem również w zwalczaniu nietolerancji, ciemnoty i przesądu [...] w teatrze powinno się dokonać dzieło zbratania całej ludzkości, ludzi wszystkich krajów i stanów, którzy odrzuciwszy więzy sztuczności i mody - rozumieją rzecz najważniejsza: że są braćmi" (Goethe i Schiller o dramacie i teatrze. Wybór pism, tłum. O. Dobijanka, Wrocław 1959; <http://www.e-teatr.pl/pl/programy/2011_03/28411/don_carlos_teatr_stary_krakow_1984.pdf >). 
Znaczący był więc wybór kodu, dyskursu sztuki wysokiej, w postaci kanonicznego tekstu jednego z twórców niemieckiego preromantyzmu, a następnie jego transformacja - wydobycie nowych znaczeń przez poddanie go kobiecemu/dziewczęcemu odczytaniu bohaterek, które pozwalało wyjść poza narzucający się wprost, uświęcony w tradycji niemieckiej kultury, topos miłości nieszczęśliwej, niemożliwej. Zamknięta w nim kreacja syna Filipa II - księcia Don Carlosa ze sztuki Schillera stanowiłaby tylko kostium, służący realizatorskiej strategii Froelicha, określonej przez Herthe Thiele jako „estetyzowanie stłumienia”" ${ }^{50}$. Żeński homoerotyzm, jak przypominała przed laty Inga Iwasiów, ma częstokroć znamiona „mówienia półprywatnego, marginalnego, wyciszanego. Często towarzyszy mu odium szaleństwa lub grafomanii” ${ }^{51}$. Badaczka podkreślała, że w potocznej świadomości gatunek „kobiecy” to romans ${ }^{52}$. Sagan i Winsloe udało się więc nie tylko rozbroić ową deprecjonująca kwalifikację przez - nobilitujące i legitymizujące dla kreowanej przez nie formy filmowej - zacytowanie dzieła klasyka weimarskiego. Dzięki wybranej przez nie twórczej metaforze Don Carlosa dokonała się swego rodzaju transformacja filmowego dramatu o dojrzewaniu z elementami żeńskiego romansu, w uniwersalną kobieca, w tym także lesbijską opowieść o przesłaniu wolnościowym. Artystki, działające z wnętrza heteroseksualności, usiłujące innowacyjnie i pioniersko przełamać zakazy i opór, wybrały więc świadomie odwołanie do przełomowego dramatu Fryderyka Schillera, w którym markiz Poza wypowiada kwestię: „Dajcie nam wolność myślenia!" ${ }^{53}$.

Powstajacy długo Don Carlos stanowi wyrazisty ślad ostatecznej krystalizacji poglądów autora na temat wolności, ogólnoludzkich praw oraz tyranii, na szerszym uniwersalnym tle. Przesłanie tego dzieła wykracza poza pierwotnie zamierzony dramat uczuć i namiętności w odniesieniu do jednostki ${ }^{54}$. Don Carlos uznawany jest za ucieleśnienie tematu, wynikajacego z żywionych przez Goethego i Schillera „sympatii dla podstawowych społecznych wartości w opozycji do opresyjnego oświeceniowego racjonalizmu”55. Przyjaciel księcia Don Carlosa - markiz Poza - to upostaciowienie

${ }^{50}$ Hertha Thiele interviewed...

${ }^{51}$ I. Iwasiów, Gatunki i konfesje w badaniach „gender”, [w:] Lektury inności. Antologia..., s. 72 .

${ }^{52}$ Tamże, s. 74.

${ }^{53}$ F. Schiller, Don Carlos, tłum. K. Goniewski, <https://wolnelektury.pl/katalog/lektura/ schiller-don-carlos/> [dostęp: 10.09.2019]. Tomasz Kitliński i Paweł Leszkowicz określają tego typu podmioty twórcze jako tzw. „awangardę seksualna” (zob. T. Kitliński i P. Leszkowicz, dz. cyt., s. 146-147). Należy zauważyć, że B. Ruby Rich również podkreśla znaczenie wyboru sztuki Fryderyka Schillera. Zob. tejże, dz. cyt., s. 188.

${ }^{54}$ Zob. M.J. Siemek, Fryderyk Schiller, Warszawa 1970, s. 58.

${ }^{55}$ B.R. Rich, dz. cyt., s. 188 (tłum. autorki). 
liberalnego i wzniosłego idealizmu, przeciwstawionego absolutystycznemu porządkowi i władzy. Jest to, jak pisze Marek Siemek: „dzieło o «najwyższych sprawach ludzkości»: o walce i poświęceniu w imię «czystego człowieczeństwa»" ${ }^{56}$. Wolnościowy, postępowy duch obecny w twórczości zbuntowanego ucznia akademii wojskowej Księcia Karola nazywanej „plantacją niewolników" ${ }^{57}$ prowokował więc owe odwołanie w Dziewczętach w mundurkach. Don Carlos z zaznaczającym się w nim przełamaniem sentymentalnego wątku dramatu osobistego i rodzinnego, na rzecz uniwersalnego postulatu ogólnoludzkich ideałów wolnościowych, doskonale nadawał się do przywołania $\mathrm{w}$ ramach strategii intertekstualnej, opartej na negocjowaniu treści związanych z homotekstualnością - a więc nie tylko ekspresji motywu samego uczucia - czyli miłości łączącej kobiety, ale też lesbijskiej tożsamości, wraz $\mathrm{z}$ silnie powiązanym z tym aspektem dążenia podmiotu do autentyczności ${ }^{58}$.

Należy podkreślić, że gdyby reżyserka i autorka scenariusza Dziewczat $w$ mundurkach chciały ograniczyć wymowę filmu do subiektywno-emocjonalnego buntu jednostki miotanej namiętnościami, to odwołałyby się do młodzieńczych dzieł dramatycznych Fryderyka Schillera z okresu Burzy i Naporu - Zbójców oraz Intrygi i miłości, jako egzemplifikacji tego rodzaju treści ${ }^{59}$. Wybór Don Carlosa zaś, jako tekstu, który stanowił także prezentację nowego typu bohatera $\mathrm{w}$ dramaturgii Schillera, był więc znamienny i związany z ogólnym przesłaniem filmu. Wspomniany nowy protagonista to wcielenie przywódcy, uzurpatora, którego myśl i wola nakierowane były na rzeczywistość przemian społeczno-politycznych ${ }^{60}$. W dramacie taka postacią, rzecznikiem ideałów i zarazem sojusznikiem młodego idealisty - syna brutalnego władcy - jest doświadczony markiz Poza, a ich sprzysiężenie ma na celu obalenie tyrana i postęp ludzkości. Paralelnie taką też rolę inspiratorki dążeń do niepodległej pozycji i myśli swych podopiecznych, usiłującej zaszczepić młodziutkim uczennicom pragnienia oraz dążenia, wykraczające poza sztywne rygory pruskiej szkoły żeńskiej, pełni w fabule wychowawczyni - panna von Bernburg.

Przywołany tekst Don Carlosa, zgodnie z mechanizmem opisywanym przez Piotra Dobrowolskiego, stał się nie tylko ,jedynym prawdziwym odnie-

${ }^{56}$ M.J. Siemek, dz. cyt., s. 58.

${ }^{57}$ J. Szymańska, Don Carlos, „Ekran” 1973, nr 22, <http://www.e-teatr.pl/pl/artykuly/111110,druk.html> [dostęp: 10.09.2019].

${ }^{58}$ Warto w tym kontekście przywołać bliskie Schillerowi rozumienie podmiotowości, rozwijane przez Johanna Gotfrieda Herdera, według którego jest ona zwiąana z „niepowtarzalnym charakterem każdego indywiduum posiadającego ową eigenes Mass «własną miarę». [...] Bycie «autentycznym» oznacza postępowanie wedle tej miary i dbanie, by nie została utracona" (M. Warchala, dz. cyt., s. 27).

${ }^{59}$ Zob. M.J. Siemek, dz. cyt., s. 57.

${ }^{60}$ Zob. tamże. 
sieniem”"1 dającym oparcie głównej bohaterce, ale również i drogowskazem moralnym dla pozostałych dziewcząt. Działanie dramatis personae stanowiło wzorzec postępowania, a tekst niósł, w kontekście całej twórczości Fryderyka Schillera, zasadnicze rewolucyjne przesłanie dążenia do fundamentalnych ludzkich wartości, powiązanych w filmowej fabule także z prawem podmiotu do zmierzania ku autentyczności. Literatura, która zgodnie z psychoanalityczną koncepcją intelektualizacji życia popędowego w okresie dojrzewania, a więc skojarzenia „uczuć i procesów popędowych z ich słownymi reprezentacjami”"62, oferowała kostium, w którym dzięki męskiemu przebraniu mogły wyrazić się prawdziwe dziewczęce emocje i uczucia Manueli, stała się też zarazem katalizatorem odwagi i wolnościowej postawy uczennic. Sztuka Schillera, „zbójecka książka”, czyniła je zdolnymi do odrzucenia zasad ustanowionych przez surowego prawodawcę - dyrektorkę szkoły, występująca jako swoiste przedłużenie patriarchalnych sił, regulujących cały porządek świata przedstawionego.

Zgodnie z tezami Piotra Dobrowolskiego kontekst, w którym pojawia się inscenizacja fragmentu tekstu dramatycznego, pozwala wydobyć jego aktualność przez konfrontację z daną rzeczywistością społeczną i politycz$n a^{63}$. Dodać należy, że w rozszyfrowaniu uaktualnionej wymowy całości tekstu istotna rolę odgrywa świadomość wpływu cenzury (kontekst cenzury obyczajowej uobecniał się także w przypadku realizacji Dziewczat $w$ mundurkach $)^{64}$. Dokonuje się to więc zwykle poprzez dopowiedzenie i rozszerzenie znaczeń źródłowego fragmentu metafory na całość utworu, jako komentarza do danego czasu ${ }^{65}$. Kreacja świata przedstawionego Dziewczat $w$ mundurkach nie zawierała ścisłych historyczno-politycznych odniesień do rzeczywistości pozafilmowej. Nie ma w niej więc również śladu ducha wolności seksualnej, radykalnych ruchów kobiecych i swobodnej atmosfery Berlina lat dwudziestych, która przyciagała reprezentantów mniejszości seksualnych z innych krajów ${ }^{66}$. Osadzony w fabule Dziewczqt $w$ mundurkach fragment dramatyczny otwierał natomiast możliwości interpretacyjne, które pozwalały na zawoalowana diagnozę zjawisk związanych ze zmieniająca się sfera społeczno-polityczną. Istotną rolę, w przypadku wybranego przez Sagan i Winsloe Don Carlosa, odegrała również przy-

${ }^{61}$ P. Dobrowolski, dz. cyt., s. 39.

${ }^{62}$ A. Freud, dz. cyt., s. 116.

${ }^{63}$ Zob. P. Dobrowolski, dz. cyt., s. 39.

${ }^{64}$ Zob. tamże. B. Ruby Rich opisuje zakres ingerencji cenzorskich w amerykańskiej wersji filmu. Zob. tejże, dz. cyt., s. 204; V. Russo, dz. cyt., s. 44.

${ }^{65}$ Zob. P. Dobrowolski, dz. cyt., s. 37.

${ }^{66}$ Zob. B.R. Rich, dz. cyt., s. 200-203; I. Luba, Berlin. Szalone lata dwudzieste - nocne zycie $i$ sztuka, Warszawa 2013. 
woływana już świadomość roli i miejsca tego dramatu w całej twórczości Fryderyka Schillera. W związku z powyższymi założeniami należy więc przypomnieć, że film powstał w okresie, kiedy narodowy socjalizm stawał się siła polityczną tuż przed dojściem do władzy Hitlera, które przyniosło zagrożenie nie tylko dla Żydów, ale także dla przedstawicieli mniejszości seksualnych. Oznaczało ono pacyfikację ruchu na rzecz zniesienia karalności homoseksualizmu (uznanego przez nazistów za zagrożenie dla niemieckiego narodu); w początkach 1933 roku zakazano działalności organizacji zrzeszających homoseksualistów, wydawania przez nich pism, zamknięto też kluby i lokale dla nich, a 6 maja 1933 roku zlikwidowano „berliński Instytut Seksuologiczny, założony i kierowany przez Magnusa Hirschfelda, który

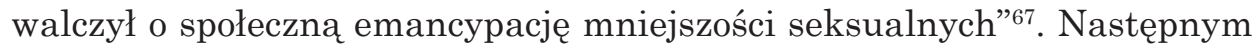
krokiem były więzienie, tortury oraz ich planowa eksterminacja w latach 1933-1945 w obozach koncentracyjnych ${ }^{68}$.

Piotr Dobrowolski charakteryzuje postawę realizatorów, którzy inkorporowali tekst dramatyczny do świata przedstawionego filmu: „Dążąc do sportretowania prawdziwych przeżyć, uciekali w jawną - konwencjonalna, sceniczną - wersję tej właśnie teatralności”"69. Tezę tę należy odnieść także do negocjowanych przez Sagan i Winsloe prób wpisania homotekstualności w strukturę Dziewczat w mundurkach, co uwarunkowane było wspomnianymi społeczno-politycznymi okolicznościami realizacji filmu. Kreacja obrazu, w którym momentem zwrotnym fabuły jest sytuacja publicznego coming outu zakochanej w wychowawczyni dojrzewajaccej dziewczyny, została więc oparta i konsekwentnie wyprowadzona z przywołanej wcześniej sceny z Don Carlosa, której ładunek emocjonalny jest ściśle powiąany z kategoria autentyczności. Ruby Rich przypomina, że jest to wyjątkowa w całym utworze scena audiencji i intymnej rozmowy Don Carlosa z królowa, podczas której książę, nie mogąc znieść niesprawiedliwości wynikłej z woli ojca, który poślubił jego narzeczona, deklaruje królowej Elżbiecie swą zakazaną miłośćc ${ }^{70}$. Oczywista paralela postaci, w którą wciela się Manuela i jej samej łączy się z doświadczaną przez nich oboje - księcia oraz uczennicę - miłością niemożliwa, nieszczęśliwą (przez władających uznaną za zakazana), jak również z determinacją prowadzącą do wyznania owego

${ }^{67}$ P. Fijałkowski, dz. cyt., s. 127. Zob. M. Herzer, Magnus Hirschfeld. Leben und Werk eines jüdischen, schwulen und sozialistischen Sexologen, Hamburg 2001, s. 230-234.

${ }^{68}$ Zob. A. Pretzel, G. Roßbach, „Wegen der zu erwartenden hohen Strafe”. Homosexuellenverfolgung in Berlin 1933-1945, Berlin 2000; Nationalsozialistischer Terror gegen Homosexuelle: verdrängt und ungesühnt, red. B. Jellonnek, R. Lautmann, F. Schöningh, Paderborn 2002; D.A. Hackett, The Buchenwald Report, Oxford 1995; G. Grau, C. Schoppmann, The Hidden Holocaust? Gay and Lesbian Persecution in Germany 1933-45, Chicago 1995.

${ }^{69}$ P. Dobrowolski, dz. cyt., s. 42.

${ }^{70}$ Zob. F. Schiller, Don Carlos, tłum. K. Goniewski...; B.R. Rich, dz. cyt., s. 188. 
uczucia $^{71}$. Infanta - syna Filipa II, którego losy, wpisane w czarną legendę władcy, stały się kanwą dramatu Schillera, oraz główną bohaterkę filmu łączy także osierocenie przez matkę, narzucona im obojgu przez rządzących izolacja od otoczenia, jak również grożąca im młodzieńcza heroiczna śmierć jako wynik niesprawiedliwych praw ${ }^{72}$.

Pomimo implikowanych przez szkolny spektakl kategorii umowności, udawania, kostiumu i roli, sceniczne wcielenie Manueli w hiszpańskiego księcia doświadczającego miłości niemożliwej, nieszczęśliwej, wykracza poza grę, stając się świadectwem szczerości i intensywności jej przeżyćc ${ }^{73}$. Główna bohaterka filmu przekracza też męską rolę Don Carlosa - zalotnika (w której odnosi sukces w szkolnym przedstawieniu), podejmując próbę ekspresji własnych prawdziwych i zarazem zakazanych, skrywanych w podświadomości, uczuć w obecności innych dziewcząt ${ }^{74}$. Manuela upojona sukcesem przedstawienia, rozemocjonowana, reagując na swobodna atmosferę tanecznego wieczorku dla uczennic, któremu towarzyszą wznoszone ponczem toasty, ogłasza spontanicznie miłość do panny von Bernburg i wypowiada zdania: „Tak, wszyscy powinni wiedzieć. Nic nie ma znaczenia. Jest tam i zależy Jej na mnie. Nie boję się niczego! Ani nikogo!’”5. Scena wcześniejszego miłosnego wyznania z dramatu Schillera staje się więc nie tylko maską dla własnych przeżyć uczennicy, ale też narracyjnym kluczem do wyjścia z emocjonalnej niestabilności, wynikającej ze stłumienia jej tożsamości i zarazem katalizatorem, który dynamizuje fabułę, wyzwalając rozwiązanie prowadzące Manuelę jako podmiot ku autentyczności. Ujawniając publicznie uczucie, którym darzy pannę von Bernburg dokonuje ona wyjścia z ukrycia i młodzieńczego określenia swej seksualnej tożsamości. Zaznaczyć warto, że czynnik alkoholu, który temu towarzyszy, stanowić może element wspomagajacy zawieszenie mechanizmów stłumienia i jawną artykulację uczuć ${ }^{76}$. Może się

${ }^{71} \mathrm{~W}$ dramacie Schillera istotny jest fakt, zgodny z prawdą historyczna, że to Książę Asturii był pierwotnie zaręczony z Elżbietą Walezjuszka. Jednak jego ojciec Filip II poślubił narzeczoną syna, czyniąc ją tym samym macochą Don Carlosa. Zob. Z. Wójcik, Historia powszechna. Wiek XVI-XVII, Warszawa 2008, s. 270; H. Kamen, Philip of Spain, Yale Press 1998.

${ }^{72}$ Zob. tamże. Powstała już po śmierci infanta romantyczna legenda, powiązana ze spekulacjami dotyczącymi jego domniemanego zabójstwa przez ojca, nie odnosiła się do źródeł mówiacych o wczesnych oznakach choroby psychicznej, które osierocony zaraz po narodzinach i doświadczający licznych chorób w dzieciństwie, młody książę miał ujawniać, a które mogły być również genetycznym efektem małżeństw osób blisko spokrewnionych, wynikających z polityki dynastycznej Habsburgów. Zob. S. Grzybowski, Henryk Walezy, Wrocław-Warszawa-Kraków-Gdańsk-Łódź 1985, s. 35.

${ }^{73}$ Por. P. Dobrowolski, dz. cyt., s. 39.

${ }^{74}$ Hertha Thiele w wywiadzie opisuje tę scenę jako wybuch treści podświadomych. Zob. Hertha Thiele interviewed...

${ }^{75}$ Fragment ścieżki dźwiękowej filmu.

${ }^{76}$ Por. K. Boczkowski, Homoseksualizm, Warszawa 1992, s. 185. 
on jednak również wiąać, jako realistyczna motywacja działania bohaterki, z realizatorskim dążeniem Froelicha do neutralizowania homoerotycznej wymowy Dziewczat $w$ mundurkach.

Należy więc podkreślić, że zobrazowana w filmie sytuacja publicznego wyznania powiązana jest z obecnością kilku czynników, na które wskazuje Jerzy Krzyszpień w swej pracy poświęconej doświadczeniu coming outu ${ }^{77}$. Istotne jest więc to, że wychodzenie Manueli z ukrycia odbywa się wobec osób szczególnie dla niej ważnych, z którymi łączy ją wspólnotowa więź ${ }^{78}$. Można zarazem w przywoływanej scenie dostrzec znamiona wybiórczego coming outu, gdyż wyznanie wypowiadane jest wobec dziewcząt, które najprawdopodobniej zaakceptują ją i dadzą wsparcie (fakt, że dowiaduje się o tym dyrektorka szkoły, nie jest jej intencja, a stanowi jedynie wynik przypadkowej obecności jednej z opiekunek) ${ }^{79}$. Język, którym Manuela opisuje swe młodzieńcze uczucie, jest „przyjazny i pozytywny” ${ }^{\circ 0}$, „wwyczajny i jasny” ${ }^{2}$. Daje też ona do zrozumienia, że ze swymi uczuciami, a więc i z określona seksualnościa, czuje się dobrze ${ }^{82}$. Sytuacja życiowa bohaterki - sieroctwo sprawia, że nie pojawia się w filmie wątek ujawnienia wobec rodziców czy rodziny ${ }^{83}$. Natomiast charakterystyka Manueli oraz jej relacji ze szkolna społecznością wskazuje, że wrażliwością i przyjazną postawa zyskała ona w pozostałych uczennicach sojuszników. Jest to grono rodziny z wyboru, empatycznie słuchającej i reagującej, na którą w zwiąku z konsekwencjami publicznego wyznania będzie mogła w przyszłości liczyć, pomimo że interwencja dyrektorki zapobiega temu, by wyznanie, przerwane omdleniem Manueli, rozwinęło się w szczera rozmowę dziewcząt z nią ${ }^{84}$.

Wraz z coming outem głównej bohaterki filmu następuje radykalne przekroczenie narzuconych reguł i nazwanie tego, co prawodawcy świata przedstawionego, upostaciowieni w osobie dyrektorki szkoły, uznaja za zabronione i wyparte. Ruby Rich zauważa: „Niepotwierdzony de facto erotyzm może być zawarty w całej rozciagłości panującego patriarchalnego porządku" ${ }^{\prime 5}$. Przywołuje też ona subtelne symptomy homoerotycznej aury dostrzegalnej w szkole, które stanowią uzasadnienie dla tej tezy ${ }^{86}$. Najistot-

${ }^{77}$ Zob. J. Krzyszpień, Wychodzimy z ukrycia. Ujawnianie się lesbijek, gejów, biseksualnych i trans płciowych+, Kraków 2018.

${ }^{78}$ Zob. tamże, s. 69.

${ }^{79}$ Zob. tamże, s. 72-73.

${ }^{80}$ Tamże, s. 69.

${ }^{81}$ Tamże, s. 76.

82 Zob. tamże, s. 72.

${ }^{83}$ Zob. tamże, s. 73.

${ }^{84}$ Zob. tamże, s. 146.

${ }^{85}$ B.R. Rich, dz. cyt., s. 189 (tłum. autorki).

${ }^{86}$ Zob. tamże. 
niejszym homoerotycznym motywem wizualnie sportretowanym $\mathrm{w}$ filmie jest wieczorny pocałunek przed snem, który wychowawczyni składa na ustach uczennicy. Jednak to transgresja dokonana przez Manuelę, jako groźne i niewybaczalne publiczne naruszenie tabu, skutkuje natychmiastową decyzją o całkowitej izolacji zakochanej dziewczyny, która dyrektorka definiuje jako zdeprawowaną i stanowiącą zagrożenie dla społeczności szkoły. Wątek ten stanowi nawiązanie do losów Don Carlosa, księcia Asturii, którego ojciec Filip II Habsburg skazał na odosobnienie, w związku z czym infant, cierpiący na narastające w izolacji psychiczne dolegliwości, zmarł przedwcześnie w wieku 23 lat ${ }^{87}$. Umieszczenie Manueli w izolatce ma symboliczny wymiar kary wymierzonej przez przedstawicielkę patriarchalnego oficjalnego porządku, a zarazem stanowi aluzję do pseudonaukowych diagnoz i metod, którymi usiłowano „leczyć” homoseksualizm jako wrodzona chorobę i zaburzenie psychiczne ${ }^{88}$.

Kontekst literacki wzmacniał więc siłę obrazu izolacji, jako nawiązującego do ówczesnego represyjnego prawa, a więc paragrafu 175, na podstawie którego od 1871 roku w Niemczech karano homoseksualistów więzieniem i którego zakres usiłowano rozszerzyć w roku 1909, obejmując nim także kobiety - lesbijki ${ }^{89}$. Odwołanie do dramatu stanowiło też tło, dla ukazanego w filmie procesu psychicznej opresji oraz stanu amnezji, której w szkolnej izolatce doznaje Manuela. Dziewczęta $w$ mundurkach odsłaniały więc nie tylko mechanizm wywołujący wysoki stopień stresu, którego w związku z dyskryminacja - komunikacyjną oraz fizyczną izolacją doświadcza wrażliwa psychika młodej bohaterki i który wywołuje w niej skłonności samobójcze, ale też mogły budzić pewne skojarzenia z obowiąującym restrykcyjnym prawem $^{90}$. Pomimo że radykalne działania przedstawicielki opresyjnego systemu służą odseparowaniu Manueli od społeczności uczennic, to oswojone z jej wrażliwością dziewczęta zamiast odrzucić i zamknąć się na nia, odpowiadaja jednakże wsparciem, które przynosi ratunek w dramatycznych

${ }^{87}$ Niektóre źródła wskazują też na zagłodzenie lub otrucie jako przyczynę przedwczesnej śmierci księcia Don Carlosa. Zob. Z. Wójcik, dz. cyt. Jednak współcześni historycy, np. Geoffrey Parker, przekonuja, że zmarł on śmiercią naturalna, a wspomniane tezy są wynikiem czarnej legendy Filipa II (zob. tegoż, Philip II, Open Court 2002.). Fakt, że hiszpański władca był gorliwym katolikiem, żarliwie zwalczającym herezję, stanowił jej ważny element. Zgodnie z czarną legendą ze względu na okrucieństwo, despotyzm, fanatyzm, nietolerancję i bigoterię zyskał on u protestantów przydomek „Szatana Południa”. Zob. Ch. Gibson, The Black Legend: Anti-Spanish Attitudes in the Old World and the New, Knopf 1971.

${ }^{88}$ Zob. J. Drescher, Queer Diagnoses: Parallels and Contrasts in the History of Homosexuality, Gender Variance, and the Diagnostic and Statistical Manual, "Archives of Sexual Behavior" 2010, nr 39, s. 427-460.

${ }^{89}$ Zob. Nationalsozialistischer Terror...; G. Grau, C. Schoppmann, dz. cyt.

${ }_{90}$ Zob. J. Krzyszpień, dz. cyt., s. 75. 
okolicznościach. Istotne jest więc w Dziewczętach w mundurkach także to, że nawet jeżeli spontaniczna rebelia uczennic nie obala ostatecznie rządów dyrektorki, to zakochana w wychowawczyni dziewczyna nie wróci już do izolatki i nie pozostanie zgodnie z opresyjnymi wymogami odseparowana. Finał filmu przekonuje, że to właśnie wytworzony przez dziewczęcą społeczność system wsparcia pozwala Manueli poradzić sobie z ogromnym napięciem psychicznym i ocala ją przed samobójczą śmiercia ${ }^{91}$.

Należy również podkreślić, że siła dążenia do autentyczności i ekspresji, a więc publicznego ogłoszenia przez bohaterkę zakazanego uczucia prowokuje także, inaczej niż to miało miejsce w literackim pierwowzorze, watek dochodzenia wychowawczyni do własnej identyfikacji, poprzez proces zmagania się z odpowiedzią na namiętne wyznanie uczennicy. Nie pozwala to pannie von Bernburg pozostać w bezpiecznych ramach prywatyzowanej seksualności, ale zarazem grozi koniecznością opuszczenia szkoły, w której jej działalność i metody były przez dyrektorkę już uprzednio traktowane jako nieprawomyślne, rewolucyjne ${ }^{92}$. Kontrast kreacji ulubionej w internacie wychowawczyni - idola, swoistej opiekuńczej bogini, odpowiednika czułej matki z wyniosła, władcza, pozbawioną empatii przełożona, spełniającą rolę krzewiciela patriarchalnych reguł w żeńskim gimnazjum, posłużył zaakcentowaniu autentyzmu, jako czynnika warunkującego mechanizm adoracji, którą dziewczęta darzą pannę von Bernburg ${ }^{93}$. Stanowi on także element inicjujący wątek miłosnego przyciagania, którego wobec wychowawczyni doświadcza Manuela; dzięki empatyczności, życzliwemu zainteresowaniu, otwartości na inną osobę, zawiązuje się nić relacji łączącej te bohaterki. Postawa charyzmatycznej panny von Bernburg koresponduje z głębokim pragnieniem szczerości i autentyczności w nowoprzybyłej sierocie, uruchamia w niej także potrzebę artykulacji emocji. Jednakże relacja tych postaci podlega zarazem mechanizmowi tłumienia, wyzwalającemu się wobec reguł rzeczywistości szkolnej jako opresyjnego systemu.

Jeżeli więc Manuela przywodzi skojarzenia z Don Carlosem, to w postaci i postawie panny von Bernburg odbijają się rysy dwóch postaci cytowanego dramatu Schillera - królowej Elżbiety (Walezjuszki), która odwzajemniając w skrytości miłość Don Carlosa, gotowa jest poświęcić swe osobiste uczucia, będąc stronniczką szerszej idei wolnościowej oraz markiza Pozy, jako nie

${ }^{91}$ Por. tamże, s. $75-76$.

${ }^{92}$ Por. B.R. Rich, dz. cyt., s. 191.

${ }_{93}$ Relacja podopiecznych z panną von Bernburg przypomina zjawisko opisywane przez Ann Freud w odniesieniu do dojrzewającej jednostki, która podlega skłonności do identyfikacji: „obiektem przywiązania staje się osoba nieco starsza, uznawana za lidera, a wyraźnie pełniąca funkcję substytutu porzuconych obiektów rodzicielskich” (tejże, dz. cyt., s. 119; por. S. de Beauvoir, Druga płeć, tłum. G. Mycielska, M. Leśniewska, Warszawa 2003, s. 374-375). 
tylko rzecznika wzniosłych ideałów, propagatora i inspiratora działań, które mają rozsadzić monarchiczną rzeczywistość i obalić tyranię, ale też gotowego oddać życie za księcia ${ }^{94}$. Kreacja wychowawczyni oscyluje między narzucanym sobie pewnym dystansem, wynikającym z konieczności tłumienia uczuć, niezgodnych z regułami patriarchalnego systemu, a potrzebą czułości, tkliwości oraz świadomością wagi kształtowania osobowości na fundamencie dążenia do autentyczności jako wartości formującej dla młodziutkich kobiet ${ }^{95}$. Śladem pewnego określenia się tej postaci jest wybór panieństwa i pracy wychowawczyni jako umożliwiającej życie poza małżeństwem. Ruby Rich podkreśla zaś, że wychowawczyni, w pełni zdając sobie sprawę z konsekwencji nazwania swych uczuć oraz niemożliwości realizacji „erotycznej

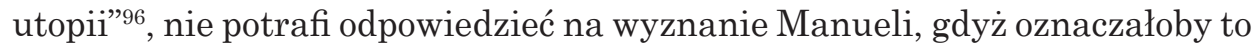
skonfrontowanie się z własną lesbijską tożsamością ${ }^{97}$. Obawiając się jednak przede wszystkim o los Manueli w konfrontacji z autorytarnym porządkiem szkoły, panna von Bernburg usiłuje więc przekonywać ją podczas osobistej rozmowy, że musi „wyzdrowieć” ze swego emocjonalnego stanu, i dodaje: „Nie wolno Ci kochać mnie tak bardzo" ${ }^{98}$. Rozwój osobowościowy, powiazany z trudnościami własnego tożsamościowego określenia się wychowawczyni, prowadzi jednakże w konsekwencji, zgodnie z jej wcześniej deklarowanym humanistycznym idealizmem, do wystapienia przeciwko dyrektorce w obronie uczennicy i wypowiedzenia zdania: „Co pani nazywa grzechem, ja nazywam wielkim duchem miłości, w każdej jego postaci”"99. Panna von Bernburg $\mathrm{w}$ ostatniej sekwencji filmu - tryumfalnie stojacca na schodach w otoczeniu dziewcząt to, jak zauważa Ruby Rich, obraz, który może oznaczać zamanifestowanie wsparcia i uznania jej seksualności przez uczennice ${ }^{100}$. Nie jest on jednak równoznaczny z odpowiedzią na uczucie Manueli.

Dziewczęta $w$ mundurkach obrazuja sieć relacji, których elementem wspólnym jest postrzeganie kobiet przez kobiety. Jest to film bez mężczyzn ukazanych na ekranie; jego obsada jest wyłącznie żeńska. Męski punkt widzenia obecny jest jednak w sferze wizualnej poprzez symboliczne ujęcia rzeźb przedstawiających postaci wojowników, w fabularnej poprzez odwołania do tradycyjnych, zgodnych z patriarchalnym porządkiem, ról

${ }^{94}$ Por. B.R. Rich, dz. cyt., s. 188; <http://www.e-teatr.pl/pl/programy/2011_03/28411/ don_carlos_teatr_stary_krakow_1984.pdf> [dostęp: 10.09.2019].

${ }^{95}$ Zob. Hertha Thiele interviewed...

${ }^{96}$ Określeniem tym posłużyła się w przywoływanym wywiadzie Hertha Thiele. Zob. tamże; K. Gramann, H. Schlüpmann, 'Momente erotischer Utopie - ästhetisierte Verdrängung', "Frauen und Film" 1981, nr 28, s. 28-47.

${ }^{97}$ Zob. B.R. Rich, dz. cyt., s. 190.

${ }^{98}$ Fragment ścieżki dźwiękowej filmu.

${ }^{99}$ Fragment ścieżki dźwiękowej filmu.

${ }^{100}$ Zob. B.R. Rich, dz. cyt., s. 193. 
żon i matek żołnierzy, a w audialnej poprzez dźwięk trąbki dobiegający do szkoły z pobliskich koszar ${ }^{101}$. Mężczyźni warunkują ukazaną w Dziewczętach $w$ mundurkach rzeczywistość diegetyczna; sa niewidzialną ramą dla owej żeńskiej enklawy. Ustanawiają oni jej prawa, narzucają też obowiązujące w niej wyobrażenia. Dziewczęta podlegają izolacji i metodom kształcenia na wzór koszar, a w przyszłości mają pełnić społeczne i życiowe role przypisane im w patriarchalnym systemie. Filmowy świat stanowi eksplikację procesów powiązanych z tłumieniem autentycznych pragnień i potrzeb młodziutkich bohaterek.

Zarazem jednak zobrazowane przez reżyserkę i scenarzystkę swoiste kalki wybranych męskich zachowań i powiązanych z nimi kulturowych konstruktów, zbliżające się do parodii (rubaszny charakter sceny napinania biustu przez jedna z uczennic; klaps wymierzany Ilsie przez pannę von Bernburg; kult fotosów popularnego amanta, związany z jego seksapilem; toasty upojonych ponczem uczennic), posłużyły wyakcentowaniu czynnika autentyczności jako wpisanego w wizję dziewczęcej wspólnoty. Wydobywający zaś sztuczność element naśladowania męskiego modelu postępowania, opartego na sile i hierarchicznym podporządkowaniu, zaznacza się szczególnie wyraźnie w odniesieniu do reprezentujących opresyjny system opiekunek oraz dyrektorki. Jej postać, jako wcielenie swoistego maskulinistycznego pierwiastka w diegezie, symbolizuje najwyższy stopień alienacji z kobiecego świata. Szczególnie kontrastuja z nią więc kreacje młodziutkich bohaterek, które charakteryzuje dziecięca naturalność, spontaniczność, swoboda w traktowaniu własnego ciała, jak również okazywana wobec innych dziewcząt troskliwość (gesty, przytulenia, pomoc w pielęgnacyjnych zabiegach). Należy też podkreślić, że w bogatej sieci ukazanych w filmie relacji kobiecych wektor autentyzmu determinuje właśnie te, które przebiegają między uczennicami. Przejawia się to poprzez wysoki stopień szczerości i jawności w ich rozmowach, wyznaniach; poprzez artykułowanie potrzeb i tęsknot odnoszących się do sfery wartości i emocji, a także w postawie otwartości i gotowości do poszukiwania idola - jako aksjologicznego wzorca ${ }^{102}$. Jest to idylliczna wizja współbytowania młodziutkich kobiet jako podmiotów, które tworzą wspólnotę opartą na żywych emocjonalnych więziach. Autentyczność występuje więc w tym ujęciu jako charyzma osoby, jej wiarygodność, która objawia się poprzez wolę bycia soba, potrzebę osobistego wyrażenia się. Opowieść filmowa Leontine Sagan prowokuje tezę, że owa postawa jako etap w rozwoju kobiet, pod presją zewnętrznego świata zanika. Stanowi ona w pewnym sensie zapowiedź diagnoz, które po II wojnie światowej za-

${ }^{101}$ Por. tamże, s. 196; S. Kracauer, dz. cyt., s. 209.

102 Zob. A. Freud, dz. cyt., s. 118-120. 
warła w Drugiej ptci Simone de Beauvoir, pisząc o kondycji dojrzewającej dziewczyny:

\begin{abstract}
Dotychczas była jednostką autonomiczna - teraz musi zrezygnować z suwerenności. Jest nie tylko rozdarta, jak jej bracia, między przeszłością a przyszłościa, i to w znacznie silniejszym stopniu; zachodzi u niej ponadto konflikt między pierwotnym dążeniem do podmiotowości, aktywności, wolności a - z drugiej strony - dążeniami erotycznymi i socjalną zachęta, która każe jej przyjać rolę biernego przedmiotu. Odruchowo odczuwa siebie jako coś istotnego, jakże się więc zdecyduje na stanie się tym, co nieistotne? Lecz, jeśli nie mogę spełnić się jako Inne, jakżebym mogła zrezygnować ze swego Ja? Oto niepokojący dylemat, z którym mocuje się kobieta u progu dojrzałości. Oscylując między pragnieniem a wstrętem, między nadzieja a strachem, odrzucając to, co przeżywa - trwa jeszcze w zawieszeniu między chwila dziecięcej niezależności a kobiecej uległości i właśnie ta niepewność daje dziewczynce pod koniec niewdzięcznego okresu cierpki smak niedojrzałego owocu ${ }^{103}$.
\end{abstract}

Siła indywidualizmu, jednostki przekraczającej w kierunku autentyczności zakazy i ograniczenia (które znajdują wyraz w mechanizmach tłumienia), ujawnia się w filmowym obrazie Dziewczęta w mundurkach na kilku poziomach; przede wszystkim poprzez wystapienie publiczne Manueli, ale i symptomy tożsamościowej ewolucji panny von Bernburg, jak również w zwielokrotnionym etycznym wyborze dokonywanym w finale przez żeńską wspólnotę. Dziewczęta nie pozostają bierne wobec niesprawiedliwości i opresji dotykajacych jedna z nich, gotowe są wzniecić rebelię w obronie prawa Manueli do jej tożsamości i uczuć. Działania, które ratują życie zdesperowanej dziewczynie, korespondują z odwaga głoszonego przez nią coming outu i sa zarazem konsekwentnym wyrazem postawy, wywiedzionej z dramatu Schillera, która odwołuje się przecież do ogólnoludzkich wartości - sprawiedliwości, braterstwa/siostrzeństwa, solidarności ${ }^{104}$. Wybierając owe wartości, legitymizują one też wolność i uczucia innych - kobiet, lesbijek. Właśnie w odniesieniu do sekwencji wspólnotowego gestu uczennic, ujawniają się przesłanki do interpretacji filmu jako ekranowego coming outu, który miał, jak przekonuje Ruby Rich, prowokować widzów do uświadomienia sobie praw tej społeczności do równego traktowania ${ }^{105}$. W filmie stworzonym przez Sagan we współpracy z Froelichem uczucie miłości, łączące dwie osoby, jest jednak ważniejsze niż odniesienia historyczno-polityczne ${ }^{106}$. Jego zobrazowanie zaś nie jest też ściśle przyporządkowane i bezwzględnie uwarunkowane realiami jakiegoś określonego czasu ${ }^{107}$. Wizja rodzącej się w żeńskiej

${ }^{103}$ S. de Beauvoir, dz. cyt., s. 365.

${ }^{104}$ Zob. J. Krzyszpień, dz. cyt., s. 75; M.J. Siemek, dz. cyt., s. 56.

${ }^{105}$ Zob. B.R. Rich, dz. cyt., s. 193.

${ }^{106}$ Zob. K. Fest, dz. cyt., s. 467.

${ }^{107}$ Zob. tamże, s. 465. 
szkolnej enklawie relacji Manueli i panny von Bernburg wraz z procesem jej tożsamościowego zinternalizowania oraz podjętą próbą ekspresji, która zyskuje walor autentyczności dzięki odrzuceniu mechanizmu stłumienia, stanowi natomiast zarówno antycypację, jak i repetycję doświadczeń licznych kobiecych istnień różnych czasów. Jest to więc wizja, która nie tylko przekracza heteroseksualny model narracji, ale przede wszystkim oparta jest na wielorakiej, mnogiej podmiotowości. Uniwersalność przekazu Dziewcząt $w$ mundurkach ma też swe głębokie źródło w literackiej metaforze zaczerpniętej z twórczości Fryderyka Schillera jako głosiciela ogólnoludzkiej idei wolnościowej oraz romantycznej antropologii uprawomocniającej osobowość, stanowiąca obszar „realizacji postulatu autentyczności”108.

\section{BIBLIOGRAFIA}

Acker A., Reel Women. Pioneers of the Cinema, 1896 to the Present, New York 1991.

Barker J., Indifference, Identification, and Desire in Virginia Woolf's Three Guineas,

Leni Riefenstahl's The Blue Light and Triumph of the Will, and Leontine Sagan's

Mädchen in Uniform, "Women in German Yearbook" 2010, nr 1, s. 73-96.

Beauvoir S. de, Druga płeć, tłum. G. Mycielska, M. Leśniewska, Warszawa 2003.

Bielik-Robson A., Erros. Mesjański witalizm i filozofia, Kraków 2012.

Bleys R.C., Images of Ambiente. Homotextuality and Latin American Art 1810 - Today, London-New York 2000.

Boczkowski K., Homoseksualizm, Warszawa 1992.

Brockmann S., A Critical History of German Film, New York 2010.

Bryant W.M., Bisexual Characters in Film: From Anaïs to Zee, Haworth Press 1997.

Cichoń E., Szczepanowski R., Mechanizmy tłumienia niepożadanych odczuć i myśli $w$ ujęciu metapoznawczym, „Rocznik Kognitywistyczny” 2015, nr 8.

Dobrowolski P., Historie równoległe, zbieżne, przeciwstawne. Teatr dramatyczny $w$ filmie jako alternatywa i dopetnienie fabuty, „Kwartalnik Filmowy” 2014, nr 87-88.

Drescher J., Queer Diagnoses: Parallels and Contrasts in the History of Homosexuality, Gender Variance, and the Diagnostic and Statistical Manual, "Archives of Sexual Behavior" 2010, nr 39.

Drewniak B., Teatr i film Trzeciej Rzeszy. W systemie hitlerowskiej propagandy, Gdańsk 2011.

Dyer R., Now You See It. Studies on Lesbian and Gay Film, New York-London 1990.

Erdelyi M.H., The Unified Theory of Repression, "Behavioral and Brain Sciences" 2006, nr 29.

Fest K., Yesterday and/or Today. Time, History and Desire in Christa Winsloe's Mädchen in Uniform, „German Life and Letters” 2012, nr 65.

Fijałkowski P., Homoseksualność daleka i bliska. Stowa, mity, symbole, Warszawa 2014. Foster G., Women Filmmakers and Their Films, Detroit 1998.

${ }^{108}$ M. Warchala, dz. cyt., s. 21. Por. M.J. Siemek, dz. cyt., s. 56, 84-85. 
Foster G.A., Women Film Directors: An International Bio-Critical Dictionary, Greenwood Press 1995.

Freud A., Ego i mechanizmy obronne, tłum. M. Ojrzyńska, Warszawa 2012.

Gibson Ch., The Black Legend: Anti-Spanish Attitudes in the Old World and the New, Knopf 1971.

Goethe i Schiller o dramacie i teatrze. Wybór pism, tłum. O. Dobijanka, Wrocław 1959.

Gramann K., Schlüpmann H., 'Momente erotischer Utopie - ästhetisierte Verdrängung', "Frauen und Film" 1981, nr 28.

Grau G., Schoppmann C., The Hidden Holocaust? Gay and Lesbian Persecution in Germany 1933-45, Chicago 1995.

Grzybowski S., Henryk Walezy, Wrocław-Warszawa-Kraków-Gdańsk-Łódź 1985.

Gwóźdź A., Zaklinanie rzeczywistości: filmy niemieckie i ich historie 1933-1949, Wrocław 2018.

Hackett D.A., The Buchenwald Report, Oxford 1995.

Hertha Thiele interviewed by Karola Gramann and Heide Schlüpmann, <http://tlweb.latrobe.edu.au/humanities/screeningthepast/reruns/thiele.html> [dostęp: 10.09.2019].

Herzer M., Magnus Hirschfeld. Leben und Werk eines jüdischen, schwulen und sozialistischen Sexologen, Hamburg 2001.

<http://www.e-teatr.pl/pl/programy/2011_03/28411/don_carlos_teatr_stary_krakow_1984.pdf> [dostęp: 10.09.2019].

Iwasiów I., Gatunki i konfesje w badaniach „gender”, [w:] Lektury inności. Antologia, red. M. Dąbrowski, R. Pruszczyński, Warszawa 2007.

Jones S.G., Mädchen in Uniform: the Story of a Film, "PerVersions: The International Journal Of Gay And Lesbian Studies" 1995/1996, nr 6.

Joseph S., Autentyczność. Jak być sobq i dlaczego jest to ważne, tłum. A. Jacewicz, Poznań 2016.

Kamen H., Philip of Spain, Yale Press 1998.

Kitliński T., Leszkowicz P., Homotekstualność: homoseksualność i twórczość, [w:] Lektury inności. Antologia, red. M. Dąbrowski, R. Pruszczyński, Warszawa 2007.

Kłys T., Od Mabussego do Goebbelsa. Weimarskie filmy Fritza Langa i kino niemieckie do roku 1945, Łódź 2013.

Kracauer S., Od Caligariego do Hitlera. Z psychologii filmu niemieckiego, tłum. E. Skrzywanowa i W. Wertenstein, Gdańsk 2009.

Krimmer E., Ideology's Work Is Never Done: A New Historicist Reading of Mädchen in Uniform, "West Virginia University Philological Papers" 1999, nr 45, s. 38-46.

Kruger L., Lights and Shadows: The Autobiography of Leontine Sagan, Johannesburg 1996.

Krzyszpień J., Wychodzimy z ukrycia. Ujawnianie się lesbijek, gejów, biseksualnych $i$ trans płciowych+, Kraków 2018.

Kuzniar A., Hesitancy and Hovering: Irony, Camp, and Fetishism in Mädchen in Uniform, „Seminar. A Journal of Germanic Studies” 2019, nr 2, s. 94-109.

Leontine Sagan. Licht und Schatten. Schauspielerin und Regisseurin auf vier Kontinenten, red. M. Eckardt, Berlin 2010.

Luba I., Berlin. Szalone lata dwudzieste - nocne życie i sztuka, Warszawa 2013. 
Maasen T., Man - Boy Friendships on Trial: On the Shift in the Discourse on Boy Love in the Early Twentieth Century, [w:] Male Intergenerational Intimacy: Historical, Socio-Psychological, and Legal Perspectives, red. T. Sandfort, E. Brongersma, A.X. van Naerssen, New York 1991.

Małyszek T., Świattopisanie. Film niemiecki 1895-2010, Wrocław 2013.

Mayenowa M.R., Wyrażenia cudzystowowe. Przyczynek do badań nad semantyka tekstu poetyckiego, [w:] tejże, Studia i rozprawy, wybór i oprac. A. Axer i T. Dobrzyńska, Warszawa 1993.

Mayer V., Lesbian Classics In Germany? A Film Historical Analysis of Mädchen in Uniform (1931 and 1958), „Journal of Lesbian Studies” 2012, nr 3, s. 340-353.

McCormick R., Coming Out of the Uniform: Political and Sexual Emancipation in Leontine Sagan's Mädchen in Uniform (1931), [w:] Weimar Cinema: An Essential Guide to Classic Films of the Era, red. N.W. Isenberg, Columbia 2009, s. 271-289.

Nationalsozialistischer Terror gegen Homosexuelle: verdrängt und ungesühnt, red. B. Jellonnek, R. Lautmann, F. Schöningh, Paderborn 2002.

Ohm L., The Filmic Adaption of the Novel The Child Manuela: Christa Winsloe's Child Heroine Becomes a Girl in Uniform, Gender and German Cinema: Feminist Interventions, red. S. Frieden i in., Berg 1993, s. 97-104.

Parker G., Philip II, Open Court 2002.

Pretzel A., Roßbach G., „Wegen der zu erwartenden hohen Strafe”. Homosexuellenverfolgung in Berlin 1933-1945, Berlin 2000.

Psychologia pozytywna w praktyce, red. P.A. Linley, S. Joseph, tłum. A. Jaworska-Surma, Warszawa 2007.

Rich B.R., Chick Flicks: Theories and Memories of the Feminist Film Movement, Duke University Press 1998.

Russo V., The Celluloid Closet. Homosexuality in the Movies, New York 1995.

Schiller F., Don Carlos, tłum. K. Goniewski, <https://wolnelektury.pl/katalog/lektura/ schiller-don-carlos/> [dostęp: 10.09.2019].

Schiller F., Don Carlos, tłum. K. Iłłakowiczówna, Warszawa 1954.

Schoppmann C., Christa Winsloe (1888-1944), tłum. D. Heymann, Berlin 2005, <www. lesbengeschichte.de> [dostęp: 10.09.2019].

Siemek M.J., Fryderyk Schiller, Warszawa 1970.

Stoodley B.H., The Concepts of Sigmund Freud, Free Press 1959.

Szymańska J., Don Carlos, „Ekran” 1973, nr 22, <http://www.e-teatr.pl/pl/artykuly/111110,druk.html> [dostęp: 10.09.2019].

Voltaire, Zaire, Paris 1991.

Warchala M., Autentyczność i nowoczesność. Idea autentyczności od Rousseau do Freuda, Kraków 2006.

Weinstein V., The Uniform in the Closet: Mädchen in Uniform in Nazi Germany, „Seminar. A Journal of Germanic Studies" 2019, nr 2, s. 144-158.

Winsloe Ch., Gestern und Heute (Ritter Nérestan), Berlin 1930.

Włodek R., Jadwiga Andrzejewska na scenie i ekranie, Kraków-Warszawa 2018.

Wójcik Z., Historia powszechna. Wiek XVI-XVII, Warszawa 2008.

Zimnik N., No Man, No Cry? The Film Girls in Uniform and Its Discourses of Political Regime, "Women in German Yearbook" 1999, nr 15, s. 161-183. 